\title{
How Technology Acceptance Model (TAM) Factors of Electronic Learning Influence Education Service Quality through Students' Satisfaction
}

\author{
Mar'atus Sholikah ${ }^{1}$, Sutirman Sutirman ${ }^{2}$ \\ ${ }^{1}$ Universitas Negeri Yogyakarta, Yogyakarta, Indonesia \\ ${ }^{2}$ Faculty of Economics, Universitas Negeri Yogyakarta, Yogyakarta, Indonesia
}

\begin{abstract}
The objectives of the study is figuring out of the results of adoption of electronic learning systems (BeSmart) using Technology Acceptance Model (TAM) factors and servqual models to measure the education services. The data was obtained using SEM with AMOS 2.4. From the findings of the study, note that EoU and $U$ of electronic learning systems hava a positive and significant effect on ESQ through student satisfaction. These findings contribute to university management to understand that service quality needs to pay attention to Ease of Use, Usefulness, and student satisfaction. This research provides insights into the importance of improving the quality of service in education and students' satisfaction, especially in the provision of service in learning and teaching field. As such, the study has implications for teaching and learning practice in higher education institution, and suggests recommendations for further research.
\end{abstract}

Keywords - service quality, student satisfaction, convenience, usefulness

\section{Introduction}

The development of technology and information greatly affect the quality of education. Therefore,

DOI: 10.18421/TEM93-50

https://doi.org/10.18421/TEM93-50

Corresponding author: Mar'atus Sholikah,

Postgraduate Student, Universitas Negeri Yogyakarta, Yogyakarta, Indonesia.

Email: maratussholikah.2019@student.uny.ac.id

Received: 25 June 2020.

Revised: 11 August 2020.

Accepted: 17 August 2020.

Published: 28 August 2020.

(c) BY-NC-ND@ 2020 Mar'atus Sholikah \& Sutirman Sutirman; published by UIKTEN. This work is licensed under the Creative Commons AttributionNonCommercial-NoDerivs 4.0 License.

The article is published with Open Access at www.temjournal.com educators are encouraged to utilize technology in their teaching as a tool to facilitate learning or as a means for formative assessment [1], [2]. Judging from the current educational trends, many universities in Indonesia use online learning systems such as e-learning with the aim of improving student learning outcomes, student satisfaction, and the quality of educational services [3].

E-learning is defined as a system in education that applies electronic applications to encourage the process of learning so that what is taught is fully conveyed to students who receive it. E-learning applications use internet, computer networks or standalone computers as an operating tool with the lecturer as the main actor, so that lecturers in this case must understand how to operate it [4]. The adoption of electronic learning like BeSmart has been shown to improve student performance [5].

However, not all learning processes carried out by lecturers and students use the portals that have been provided. In fact, Cheung \& Hew (2015); Geng, Law \& Niu (2019) revealed that online lectures can enhance the quality of educational services and outcomes of student learning [6], [7]. Improving the quality of service through the use of BeSmart must be supported by the intention to use the learning media. Intention is defined as the desire to conduct behavior [8]. Skiner defines behavior as a response or reaction to a stimulus (stimulation from outside). This is in accordance with Planned Behavior Theory (PBT) which affirms that behavior is an action carried out based on the factors that influence it. Thus, user behavior in this case is the key to success in implementing the use of the system or technology.

Much of the literature has discussed the factors associated with the process of adoption of information technology. The model of technology acceptance or TAM is one of the most dominating models of research. TAM consists of several variables that explain behavioral intentions and the use of technology both directly and indirectly. Schepers and Wetzels (2007) divide the TAM 
variable into two. First, internal variables, namely perceived usefulness, perceived ease of use, and attitudes toward technology [9]. Meanwhile the second is an external variable, namely self-efficacy, norms of subjective, and conditions of technology use. Conforming to the above opinion, there are two main constructs in TAM, namely ease of use and usefulness [8].

Usability constructs are interpreted as the level at which an individual believes that adopting a particular system can maximize their performance, while the construct of EoU (perceived ease of use) is the level at which an individual understands that in applying a system, no effort is needed [8]. Perception of usefulness (perceived usefulness) will reinforce individuals to know the usefulness (U) of electronic learning better where e-learning is designed by the campus. Perception of usefulness according to Szajna (1996) become one of the influential factors that shape behavior to use a technology with the hope that when using the utilization system, it will improve the job and performance quality [10]. EoU will affect perceptions of usability so that it encourages students to better use e-learning as a product that is needed [11].

Accessibility of e-learning itself can be used anywhere and anytime as long as the internet network is connected. Therefore, ease of access in the midst of busyness will further increase the perception of the user's usefulness. In addition, the perception of ease in the use process (EoU) encourages students to use e-learning more often [12]. Against this background it is needed to conduct research on how TAM factors can influence student satisfaction and learning outcomes. This study tries to relate the factors of the TAM model to the satisfaction and improvement of outcomes of student learning in the use of BeSmart.

\section{Methodology}

Quantitative research is carried out with the aim to measure and test empirically the influence between variables. The questionnaire used was online with 50 statement items identified through a literature review of TAM factors, student satisfaction, and quality of education services. The study population was 4,218 students where the sample used cluster sampling of 365 respondents at Yogyakarta State University. The selection of respondents is found on the use of BeSmart with a minimum of three times access.
Table 1. Measuring independent construct

\begin{tabular}{|c|c|c|}
\hline \multicolumn{2}{|c|}{ Construct } & Source \\
\hline \multicolumn{3}{|c|}{ Ease of use(EoU) } \\
\hline E1 & Easy to learn & \multirow{6}{*}[8]{} \\
\hline E2 & Controllable & \\
\hline E3 & Clear and understandable & \\
\hline E4 & Flexible & \\
\hline E5 & Easy to become skillful & \\
\hline E6 & Easy to use & \\
\hline \multicolumn{3}{|c|}{ Usefulness (U) } \\
\hline U1 & Makes job easier & \multirow{6}{*}{ [8] } \\
\hline $\mathrm{U} 2$ & Work more quickly & \\
\hline U3 & Increase productivity & \\
\hline U4 & Effectiveness & \\
\hline U5 & Improve job performance & \\
\hline U6 & Usefull & \\
\hline
\end{tabular}

Table 2. Measuring Dependent Construct

\begin{tabular}{|c|c|c|}
\hline \multicolumn{2}{|c|}{ Construct } & Source \\
\hline \multicolumn{3}{|c|}{ Students' Satisfaction (SS) } \\
\hline $\mathrm{S} 1$ & Self-efficacy & [13] \\
\hline S2 & Enjoyment & \\
\hline \multicolumn{3}{|c|}{ Education Service Quality (ESQ) } \\
\hline ESQ1 & Reliability & \\
\hline ESQ2 & Responsiveness & \\
\hline ESQ3 & Assurance & [14] \\
\hline ESQ4 & Empathy & \\
\hline ESQ5 & Tangibles & \\
\hline
\end{tabular}

\section{Hypothesis}

This study tested four variables, namely ease of use (X1), usefulness (X2), education service quality (Y), students' satisfaction (M). From these four variables the following hypothesis is formulated.

H1 : Ease of use (EoU) directly influences education service quality (ESQ)

$\mathrm{H} 2$ : Use (U) directly influences education service quality education service quality (ESQ)

$\mathrm{H} 3$ : Ease of use (EoU) influences education service quality (ESQ) through students' satisfaction (SS)

H4 : Use (U) influences education service quality (ESQ) through students' satisfaction (SS)

\section{Data Analysis}

SEM modeling approaches are used to test the model. Because the data obtained meets the test requirements using SEM with AMOS 2.4. then the data can be analyzed using the model. This study uses online survey tools to ensure confidentiality, comfort, and effectiveness. In addition, we also use SPSS 24 to test the validity and reliability of research instruments. An outline of the findings of the reliability analysis is displayed in Table 3. A Cronbach's value is higher than 0.70 for all constructs. 
Table 3. Result of reliability

\begin{tabular}{|lc|}
\hline Item & Cronbach's $\boldsymbol{\alpha}$ \\
\hline \hline EoU & 0.769 \\
Usefulness & 0.770 \\
Students' Satisfaction & 0.774 \\
Education Service Quality & 0.760 \\
\hline
\end{tabular}

We also use the KMO (Kaiser-Mayer-Olkin) test to measure adequacy in sampling. The KMO test results show that the $p$ value is 0,000 where this value is less than 0,05 while the value of KMO is 0,976 which means it is greater than 0.050 so a factor analysis can be performed.

Table 4. Summary of KMO Test Results

\begin{tabular}{||lll|}
\hline \hline KMO & & 0.976 \\
& Approx. Chi- & 19822.888 \\
Bartlett's Test & Square & \\
& Df & 1540 \\
& Sig & 0.000 \\
\hline
\end{tabular}

The analysis of confirmatory factor (CFA) was conducted to examine the effect between observed and unobserved variables [15]. CFA test results and fit value models is presented in Table 5 .

Table 5. CFA test result and fit value models

\begin{tabular}{|ccccccc||}
\hline & & & Estimates & SE & CR & P \\
\hline \hline SS & $<---$ & EoU & 0.008 & 0.022 & 0.361 & $* * *$ \\
SS & $<---$ & U & 0.020 & 0.016 & 1.217 & $* * *$ \\
ESQ & $<---$ & SS & 0.052 & 0.043 & 1.211 & $* * *$ \\
ESQ & $<---$ & U & 0.815 & 0.177 & 4.612 & $* * *$ \\
ESQ & $<--$ & EoU & 0.405 & 0.229 & 1.766 & $* * *$ \\
E6 & $<---$ & EoU & 1.000 & & & \\
E5 & $<---$ & EoU & 1.729 & 0.481 & 3.592 & $* * *$ \\
E4 & $<---$ & EoU & 0.142 & 0.298 & 0.476 & $* * *$ \\
E3 & $<--$ & EoU & 0.988 & 0.418 & 2.366 & $* * *$ \\
E2 & $<---$ & EoU & 3.279 & 1.697 & 1.932 & $* * *$ \\
E1 & $<---$ & EoU & 1.492 & 0.692 & 2.154 & $* * *$ \\
U6 & $<---$ & U & 1.000 & & & \\
U5 & $<---$ & U & 1.040 & 0.178 & 5.837 & $* * *$ \\
U4 & $<---$ & U & 0.936 & 0.166 & 5.648 & $* * *$ \\
U3 & $<---$ & U & 0.839 & 0.171 & 4.892 & $* * *$ \\
U2 & $<---$ & U & 0.961 & 0.227 & 4.227 & $* * *$ \\
U1 & $<---$ & U & 0.738 & 0.198 & 3.738 & $* * *$ \\
S2 & $<---$ & SS & 1.000 & & & \\
S1 & $<---$ & SS & 17.026 & 8.773 & 1.941 & $* * *$ \\
ESQ1 & $<---$ & ESQ & 1.000 & & & \\
ESQ2 & $<---$ & ESQ & 1.255 & 0.194 & 6.486 & $* * *$ \\
ESQ3 & $<---$ & ESQ & 0.907 & 0.217 & 4.186 & $* * *$ \\
ESQ4 & $<---$ & ESQ & 0.708 & 0.195 & 3.636 & $* * *$ \\
ESQ5 & $<---$ & ESQ & 0.634 & 0.168 & 3.782 & $* * *$ \\
\hline \hline Chi-square = 50.40 & df $=147$ & CFI & 0.944 & \\
& IFI = 0.946 & RMSEA & 0.054 & & \\
\hline
\end{tabular}

Before conducting SEM testing, we confirm the validity of convergent using construct reliability or $\mathrm{CR}$ and estimated variance or AVE [16]. A summary of the results of CR and AVE is shown in Table 6.

Table 6. The validity of convergent result

\begin{tabular}{||ccccc|}
\hline Constructs & Indicators & $\begin{array}{c}\text { Loading } \\
\text { Factor }\end{array}$ & CR & AVE \\
\hline \hline \multirow{6}{*}{ Ease of use } & E1 & 0.870 & 0.819 & 0.998 \\
& E2 & 0.864 & & \\
& E3 & 0.895 & & \\
& E5 & 0.867 & & \\
& E6 & 0.895 & & \\
& U1 & 0.905 & & \\
Usefulness & U2 & 0.932 & 0.862 & 0.972 \\
& U3 & 0.919 & & \\
& U4 & 0.929 & & \\
Students' & U6 & 0.921 & & \\
Satisfaction & S2 & 0.918 & & \\
& Q1 & 0.270 & 0.525 & 0.569 \\
Education & Q2 & 0.922 & & \\
Service & Q3 & 0.909 & 0.822 & 0.954 \\
Quality & Q4 & 0.888 & & \\
& Q5 & 0.884 & & \\
\hline
\end{tabular}

The value of AVE and CR is higher than 0,4-0,5 and 0,7 so this means that both of them exceed the specified value [15], [16]. The GoF index of the structural model is demonstrated in Table 7. which produced a higher value than received, so it can be said that our model is passed the test.

Table 7. Structural model GoF indices

\begin{tabular}{|c|c|c|c|}
\hline Fit Index & Values & $\begin{array}{c}\text { Critical of } \\
\text { Acceptable } \\
\text { Value }\end{array}$ & Acceptability \\
\hline Chi2/ Df & 0.342 & $0.002-4.80$ & Yes \\
\hline Probability & 0.150 & $\geq 0.05$ & Yes \\
\hline CFI & 0.944 & $\geq 0.90$ & Yes \\
\hline IFI & 0.946 & $\geq 0.90$ & Yes \\
\hline RMSEA & 0.054 & $\leq 0.08$ & Yes \\
\hline
\end{tabular}

\section{Findings}

Path model analysis in this study exposed an appropriate structural model so that hypothesis testing is carried out using SEM (Structural Equation Modeling). The basis for making a hypothesis test is to compare the coefficient with the value of $p$ less than 0.05. All hypothesis test results were declared significant because they were less than 0.050 . 
Table 8. Hypotheses result

\begin{tabular}{|llll|}
\hline & $\boldsymbol{\beta}$ & $\mathbf{p}$ & Decision \\
\hline \hline H1 & 0.186 & 0.019 & Supported \\
H2 & 0.202 & 0.009 & Supported \\
H3 & 0.136 & 0.026 & Supported \\
H4 & 0.921 & 0.012 & Supported \\
\hline \hline
\end{tabular}

Based on the finding of testing hypothesis in Table 8., all hypotheses are accepted and supported, namely EoU and $U$ have a positive effect on ESQ. Results of testing the first hypothesis (H1), EoU affect ESQ. This proves that the easier the electronic learning usage, the quality of educational services will also improve. Supported by [17] note that significantly, the quality of service is influenced by ease of use (EoU) significantly. For the second hypothesis (Hypothesis 2), U has a positive effect on ESQ. These results are supported by the finding of [18], [19] which revealed that a person is more likely to use something because they think it is beneficial for them.

Table 9. Model of effect outcome

\begin{tabular}{|ccccc||}
\hline Outcome & Input & Direct & Indirect & $\begin{array}{c}\text { Effect } \\
\text { Total }\end{array}$ \\
\hline \hline SS & U & .020 & 0 & .020 \\
SS & EoU & .058 & 0 & .008 \\
ESQ & SS & 0 & .069 & .000 \\
ESQ & U & .815 & .001 & .816 \\
ESQ & EoU & .405 & 0 & .405 \\
\hline
\end{tabular}

Thus, specifically, EoU and $U$ have a direct and significant effect on improving the quality of service [20],[21], [22]. Similar findings from AL-Nawafleh, ALSheikh, Abdulllah, \& Abdul (2019) also reveal that service quality is positively influenced by the factors of the TAM such as EoU and $U$ [23]. Therefore, service quality positively influences user intentions to use BeSmart. As such, it is very important for the University to place appropriate resources into various activities in order to advance the service quality. This is because the quality of service is very dependent on customers and customers are the most important stakeholders in universities. Customer opinions relating the various services offered consist of quality of service [24].

Significantly, we also find a positive effect between EoU on Education Service Quality through Students' Satisfaction (Hypothesis 3). Our findings are reinforced by Adams et al. (2018) and Panyajamorn (2018), in which the study found that ease has a positive and significant effect on service quality through consumer satisfaction by [25], [26]. Improved service quality is identified with EoU of technology that supports academic activities. Ease has a potentially positive effect on buyer satisfaction
[27]. In addition, our results also illustrate that Usefulness has a positive and significant effect on Education Service Quality through Students' Satisfaction (Hypothesis 4). This is confirmed by Mahi Uddin, Kalsom Ali, and Mohammad Aktaruzzaman Khan (2018) who found that the effect of Usefulness on the technology usage in improving service quality directly [28]. Therefore, our findings prove that to improve the education service quality (ESQ), it is necessary to be alert to the TAM factors and client satisfaction as service recipients.

\section{Theoretical Contributions}

Theory contributions require certain research results that are able to contribute original insights into a phenomenon that is studied beneficial for developing organization [29]. This study grants original insight depend on empirical data about the effect of EoU and U on ESQ through SS. EoU and U are able to identify ESQ from an empirical perspective. Therefore, this research makes an important contribution in this field. Specifically, this study contributes to variables that affect service quality in improving organizational performance.

\section{Implications for Management}

Our study results have implications in education and management fields. Some of the practical implications from these findings are first, we found that determinants of the electronic learning adoption systems (perceived $U$ and EoU) had a significant influence on the ESQ. Therefore, it can be suggested to BeSmart system developers to design a system that is easy and useful to use to improve ESQ and also enhance outcomes of student learning. The research established that the system development is easy for students as well. Despite it is also suggested to educators that increasing the use of BeSmart in learning systems may not lead to better and more effective learning.

Therefore, educators must choose learning strategies that are appropriate to the characteristics of the material being taught. Second, educational institutions are advised to encourage and facilitate educators to use e-learning optimally, and ensure users use e-learning effectively. To achieve this goal, educational institutions must be responsible for providing socialization or training for students regarding the use of BeSmart systems so that they can utilize the system effectively. In addition, the research findings emphasize the influence of EoU and U on ESQ and SS. This shows that the priority for each higher education institution in the service context is to focus efforts on developing e-learning on the needs of users and institutions. 
Thus, universities should be able to assess the extent to which the development of their services is useful. Next, they must focus on EoU of the site. Another implication for management with regard to the influence of EoU and U seems to have a strong effect on quality of service and user satisfaction, because technological development in the sector of service has a strong influence on satisfaction. In addition, BeSmart as an educational service is able to provide information and facilities as the core of services in the academic field. This research shows that if e-learning services are able to offer convenience and usefulness then these factors will be able to stimulate continued use. Further research is needed to investigate other factors that can improve service quality and customer satisfaction.

\section{Conclusion}

This study has examined the influential factors of electronic learning, namely EoU, U, ESQ, SS. Hinge on the hypothesis testing results, it is known that EoU and $U$ has a significant positive effect on Education Service Quality. In addition, the Students' Satisfaction variable is able to interfere the effect of EoU and Usefulness on Education Service Quality. Thus, Yogyakarta State University must alert to the needs and customers' satisfaction. This is because customer satisfaction is an asset and includes the quality of the service they provide. In this regard, quality in service is one of the highest investments for an organization and therefore efforts to improve it become a crucial role. In addition, user satisfaction in utilizing services is a guaranteed organizational asset. The findings of this study also indicate some limitations, namely that this study only investigated the effect of basic factors of the TAM related to the use of electronic learning systems. Further research needs to be done to discover the influence of other important factors related to the use of electronic learning systems. For example, research on how UTAUT factors are linked with the electronic learning usage as a system of learning [30].

\section{References}

[1]. Bellocchi, A., Mills, K. A., \& Ritchie, S. M. (2016). Emotional experiences of preservice science teachers in online learning: The formation, disruption and maintenance of social bonds. Cultural Studies of Science Education, 11(3), 629-652.

[2]. Shute, V. J., \& Rahimi, S. (2017). Review of computer-based assessment for learning in elementary and secondary education. Journal of Computer Assisted Learning, 33(1), 1-19.

[3]. Findik-Coşkunçay, D., Alkiş, N., \& Özkan-Yildirim, S. (2018). A structural model for students' adoption of learning management systems: An empirical investigation in the higher education context. Journal of Educational Technology \& Society, 21(2), 13-27.

[4]. Šumak, B., Heričko, M., \& Pušnik, M. (2011). A meta-analysis of e-learning technology acceptance: The role of user types and e-learning technology types. Computers in Human Behavior, 27(6), 20672077.

[5]. Dyson, L. E., Litchfield, A., Lawrence, E., Raban, R., \& Leijdekkers, P. (2009). Advancing the m-learning research agenda for active, experiential learning: Four case studies. Australasian Journal of Educational Technology, 25(2).

[6]. Geng, S., Law, K. M., \& Niu, B. (2019). Investigating self-directed learning and technology readiness in blending learning environment. International Journal of Educational Technology in Higher Education, 16(1), 17.

[7]. Cheung, W. S., \& Hew, K. F. (2015). Asynchronous online discussion activities to support university students' self-directed learning: opportunities and challenges identified. International Journal of Social Media and Interactive Learning Environments, 3(1), 63-70.

[8]. Davis, F. D. (1989). Perceived usefulness, perceived ease of use, and user acceptance of information technology. MIS quarterly, 319-340.

[9]. Schepers, J., \& Wetzels, M. (2007). A meta-analysis of the technology acceptance model: Investigating subjective norm and moderation effects. Information \& management, 44(1), 90-103.

[10]. Szajna, B. (1996). Empirical evaluation of the revised technology acceptance model. Management science, 42(1), 85-92.

[11]. Venkatesh, V., \& Davis, F. D. (2000). A theoretical extension of the technology acceptance model: Four longitudinal field studies. Management science, 46(2), 186-204.

[12]. Chang, I. C., Li, Y. C., Hung, W. F., \& Hwang, H. G. (2005). An empirical study on the impact of quality antecedents on tax payers' acceptance of Internet tax-filing systems. Government Information Quarterly, 22(3), 389-410.

[13]. Zaied, A. N. H. (2012). An integrated success model for evaluating information system in public sectors. Journal of Emerging Trends in Computing and Information Sciences, 3(6), 814-825.

[14]. Parasuraman, A., Zeithaml, V. A., \& Berry, L. L. (1988). Servqual: A multiple-item scale for measuring consumer perc. Journal of retailing, 64(1), 12. 
[15]. Schreiber, J. B., Nora, A., Stage, F. K., Barlow, E. A., \& King, J. (2006). Reporting structural equation modeling and confirmatory factor analysis results: A review. The Journal of educational research, 99(6), 323-338.

[16]. Jenatabadi, H. S., \& Ismail, N. A. (2014). Application of structural equation modelling for estimating airline performance. Journal of Air Transport Management, 40, 25-33.

[17]. Wen, C., Prybutok, V. R., \& Xu, C. (2011). An integrated model for customer online repurchase intention. Journal of Computer Information Systems, 52(1), 14-23.

[18]. Bhattacherjee, A. (2001). An empirical analysis of the antecedents of electronic commerce service continuance. Decision support systems, 32(2), 201214.

[19]. Chiu, Y. L., \& Tsai, C. C. (2014). The roles of social factor and internet self-efficacy in nurses' web-based continuing learning. Nurse education today, 34(3), 446-450.

[20]. Tandon, U., \& Ravi Kiran, A. S. (2015). Nankai Business Review International Article information. Nankai Business Review International, 6(3), 2001-2012.

[21]. Kim, Y., \& Lee, H. S. (2014). Quality, perceived usefulness, user satisfaction, and intention to use: An empirical study of ubiquitous personal robot service. Asian Social Science, 10(11), 1.

[22]. Daud, A., Farida, N., \& Razak, M. (2018). Impact of customer trust toward loyalty: the mediating role of perceived usefulness and satisfaction. Journal of Business and Retail Management Research, 13(2).
[23]. AL-Nawafleh, E. A., ALSheikh, G. A. A., Abdulllah, A. A., \& Tambi, A. M. B. A. (2019). Review of the impact of service quality and subjective norms in TAM among telecommunication customers in Jordan. International Journal of Ethics and Systems.

[24]. Jancey, J., \& Burns, S. (2013). Institutional factors and the postgraduate student experience. Quality Assurance in Education, 21(3), 311-322.

[25]. Adams, D., Sumintono, B., Mohamed, A., \& Noor, N. S. M. (2018). E-Learning Readiness among Students of Diverse Backgrounds in a Leading Malaysian Higher Education Institution. Malaysian Journal of Learning and Instruction, 15(2), 227-256.

[26]. Panyajamorn, T., Suanmali, S., Kohda, Y., Chongphaisal, P., \& Supnithi, T. (2018). Effectiveness of E-Learning Design in Thai Public Schools. Malaysian Journal of Learning and Instruction, 15(1), 1-34.

[27]. Misnan, N., Zakaria, Z., \& Salleh, W. A. (2018). Service Quality: A Study of Students Satisfaction in Higher Institution. The Journal of Social Sciences Research, 490-497.

[28]. Uddin, M., Ali, K., \& Khan, M. A. (2018). Impact of service quality (SQ) on student satisfaction: empirical evidence in the higher education context of emerging economy. AL-'ABQARI: Journal of Islamic Social Sciences and Humanities, 16, 31-67.

[29]. Corley, K. G., \& Gioia, D. A. (2011). Building theory about theory building: what constitutes a theoretical contribution?. Academy of management review, 36(1), 12-32.

[30]. Venkatesh, V., Thong, J. Y., \& Xu, X. (2012). Consumer acceptance and use of information technology: extending the unified theory of acceptance and use of technology. MIS quarterly, 157-178. 